UDK 355.48:623.4(091)

https://doi.org/10.18485/fb_ic4hs.2018.2

\title{
A HISTORICAL OVERVIEW OF THE RELATION BETWEEN TECHNOLOGICAL DEVELOPMENT AND THE ABILITY TO MANAGE PERCEPTION DURING ARMED CONFLICTS
}

\section{Nenad PUTNIK*}

\begin{abstract}
From a historical perspective, advanced technologies are developed under the auspices of armies and for military purposes. The new technical and technological inventions find their immediate application in military activities, increase the power of the warring parties, change the way in which wars are planned and thus have a direct impact on the dynamics, communication, coordination, choice of strategies, and outcome of conflicts.
\end{abstract}

A particular aspect of the impact of new technological achievements on the outcome of conflicts can be traced through their indirect impact on social conflicts since they enable new ways of spreading propaganda and disinformation and perception management before, during, and after the conflict.

The manner of presenting conflicts to the public has changed significantly over time, following the evolution of means of communication. In the first wars of the second half of the nineteenth century, the availability of information was very limited - it was reduced to reporting via printed media whose dissemination was very slow. The invention of the telegraph was a step forward in information transmission because the transmission time was reduced from several weeks to several seconds. The application of more modern technological innovations in armed conflicts such as the radio (at the beginning of the twentieth century), television (in the 1960s) and, finally, the Internet additionally increased the speed of information transmission, yet it also increased the possibilities for information manipulation. This paper discusses and analyzes the impact of information and technological means during armed conflicts, following the historical development of new technologies from the second half of the twentieth century to date.

Keywords: social conflicts, warfare, information and communication technologies, propaganda

\footnotetext{
* Associate Professor, PhD, University of Belgrade Faculty of Security Studies, nputnik@fb.bg.ac.rs
} 


\section{INTRODUCTION}

In the mid-nineteenth century, the first essential change happened in the ability to communicate. This change continued over the next one hundred and fifty years in so many varieties and modalities that it took on revolutionary characteristics. For this reason, this period can be viewed either as a unique information revolution, evolutionary in character, or as three separate periods of time, equally important and considered as separate revolutions (Papp, Alberts, Tuyahov, 1997).

The first information revolution began in the mid-nineteenth century and lasted for one century. Typical communication tools of this period were the telegraph, the radio and the telephone.

The next revolution began in the mid-twentieth century and ended in the early eighties. Its assets were television, first-generation computers and satellites. Television was a step-up in comparison to the radio, with its ability to transmit more information in a more efficient format. Computers, on the other hand, increased the ability to collect, analyze and use information, while satellites created the global telecommunications infrastructure.

By the end of the 1980s and the beginning of the 1990s, modern information systems based on personal computers and computer systems appeared. The development and application of informatics and information and communication systems overshadowed everything that had been achieved in the two previous revolutions in the field of information exchange and defined the Third Information Revolution.

The technology developed in the Second and Third Information Revolution significantly strengthened the ability to use and exchange information, and freed communicators from the constraints of time, distance, and their location.

The information revolution has transformed the way wars are waged in the information era, causing changes in how societies engage in conflicts, how their armed forces wage armed conflicts, etc. Until recently, going into combat required previously obtaining enough information on the opponent's strength, one's own forces, the space and the weather. Specific knowledge of the opponent's strength, and spatial and weather characteristics are necessary for success in waging any war. However, they are not enough. Nowadays, the first task is to inform the public (the public at home, the opponent's public, and the public of the countries which are not directly engaged in the conflict) about the reasons for the conflict, its goals, and its outcome. In these activities, modern armed forces rely heavily on the latest technological achievements in the field of information and communication technologies.

Therefore, it is important to emphasize that wars are not waged only with military means and weapons, but also via information broadcast by mass media. From war zones, reporters send striking images, information and messages, which can be more or less objective. This content influences public opinion, usually serving the governments of the warring parties. Sometimes, however, it does not match the official policy of the warring parties. 


\section{THE VIETNAM WAR - THE FIRST "TELEVISION WAR"}

Marshall McLuhan, one of the greatest media scholars, called the Vietnam War the first television war. McLuhan is known for his view that there is a correlation between war and technology, and that all the wars in history were waged with the latest technologies available to each culture at the time (McLuhan, 2008). This observation is correct to include communication technologies, since all the major wars of the twentieth century favored technological advances in the field of media, and vice versa - they were conditioned by changes in the ways of communication.

During the war in Vietnam (1962-1975), television changed the relationship between military strategies and the media. Gardner notes that it was during this conflict that war was shown on television in a negative context for the first time, through short segments of ugly and unedited low-resolution black and white photographs. The impression they left was heavy and effective. The viewer had the impression that he was a direct witness to the war. The way television depicted the war idealized the conflict and glorified the American hero. New technology enabled the transmission of a vast amount of information. Receiving numerous visual and auditory stimuli, the viewer needed a sublimated interpretation of the events. This is why the reports were accompanied by comments which simplified understanding. The narrative model of stories from folk tradition was applied, where the warring sides were divided into heroes and antiheroes. At first, the war was presented as a conflict with a cruel and fanatical enemy. Some kind of identification with American ideals was being created, so the media became promoters of official government policy. Therefore, in this war, the media did not suffer any pressure or censorship. They were authorized to monitor military troops in Vietnam and had formal autonomy in reporting (Gardner, 2009).

The tacit agreement between the media and political power was breached after the Tet Offensive, and the loss of confidence in institutions helped the emancipation of television. It was only between 1968 to 1973 that television documented and broadcast the cruel truth of the war to the American public, in the foreground and in color, causing disappointment in institutions, the moral collapse of the nation, and antimilitarism of the public (Gardner, 2009).

In June 1971, the New York Times challenged the government to publish the truth about the war contained in the so-called "Pentagon papers" (US Department of Defense secret documents), including frauds during the military attack on Vietnam. Basically, the US media did not completely stop supporting the establishment, but could not avoid showing the shaken administration (Weiskopf, Willmott, 2013).

In the final years of the war, media coverage was declining and almost stopped. With the gradual withdrawal of American troops, the viewers and the readers were losing interest in this topic, as the nation had already been brought into a state of apathy towards the war. 


\section{3. "INVISIBLE WARS" - FROM THE FALKLAND ISLANDS TO THE FIRST GULF WAR}

American and British conservative governments learnt from the Vietnamese lesson - they realized that no rhetorical skill can make up for the loss of loved ones, except in the context of total war, which would bring into question the survival of the society itself. The war, therefore, had to be presented as total and inevitable, highly technologized, without images of destruction, blood and death. In other words, it had to become "invisible".

The Falklands War (1982) was the first "invisible" war in the television era (Gardner, 2009). From the very beginning of the conflict, the British government introduced information control. British correspondents' reports were subjected to double censorship the Ministry of Defense controlled the materials before they were sent, and again upon their arrival in London (Savarese, 1992).

In the second half of the 1980s, television entered its mature phase. With the development of electronic technologies and the diffusion of geostationary satellites, the number of reports and direct transmissions increased significantly. Television instrumentation led to more dramatization, which is the basis of modern political television journalism.

The First Gulf War started with the Iraqi invasion of Kuwait. When the US representatives and the Iraqi Foreign Minister failed to reach an agreement on January 9, 1991, talks began in Geneva about the upcoming war. The media were well-prepared for the beginning of this conflict.

In this war, television triumphed as a means of communication and diplomacy. Television broadcast the message based on dramatization, on events directing and the construction of characters, and symbols translated into televisioneffective faces and images.

In order to avoid the dangerous influence of journalists on public opinion, the US Military Command used two traditional instruments: censorship and the production of an alternative flow of information (Čomski, 2008). There was hence a return to information control similar to the one used during the war in Vietnam.

Many events were covered up which makes this war the most invisible war of the twentieth century (Savarese, 1992). A large number of independent media were completely excluded from the Pentagon Information Consortium. The absolute control over information allowed the Pentagon to construct and propagate a so-called painless, high-tech war without images of destruction, blood and death. It was a war dominated by images of the battle between the "evil" and the "good", with the good always emerging victorious (Barbulović et. al., 2004). 


\section{NATO AGGRESSION ON THE FR YUGOSLAVIA AND THE SECOND GULF WAR - BEGINNINGS OF THE "INTERNET WAR"}

Incapable of producing a military response to the air attacks launched by NATO in 1999, FR Yugoslavia turned to asymmetric means to counter the Alliance. While being exposed to aggression, FR Yugoslavia actively used its own mass media, foreign journalists and the Internet to influence public opinion all over the world with a view to achieving its political goal - the preservation of its sovereignty and territorial integrity.

At first glance, it may be difficult to see the manipulation of the media and the exploitation of the Internet as a coherent campaign of information operations ran by the FRY government. The efforts the Yugoslav government made at the time to shape domestic and international public opinion look primitive in comparison with the possibilities of modern information operations, which are based on cyber weapons and attacks on computer networks (Vuletić, 2017). Nevertheless, these efforts proved effective.

In order to achieve "information security", the Yugoslav establishment resorted to the strategy of media censorship and counter-propaganda management. Applying the Law on Public Information, adopted immediately before the bombing, the government suppressed several independent media operating in Serbia with the aim of preventing its citizens from accessing information from external sources (Larsen, 2000). Also, at the very outset of the war, the broadcasting of programs from Western television stations was suspended. However, the regime could not prevent the reception of these programs via satellites and the Internet, so it started a fierce counter-propaganda campaign to discredit their credibility.

The FRY government used its own media resources to present the Yugoslav perspective on the war to foreign audiences. Through the leased EUSat communication link, RTS was able to cover the whole Europe and re-broadcast the state television program in the United States (Larsen, 2000). In this way, the regime attempted to undermine the moral and legal authority of NATO through carefully selected messages.

The government also used propaganda weapons to discredit the main reason for NATO engagement - the alleged ethnic cleansing in Kosovo and Metohija. The exploitation of so-called "collateral damage" incidents was another aspect of the information operations campaign intended to discredit NATO.

In order to reach a wider audience, the establishment turned to a completely new medium for its offensive operations - the Internet.

During the first two weeks of the war, ten regime-supporting websites appeared in English. Some of these websites were privately owned, but most were run by the Federal Ministry of Information and the Yugoslav army. In addition, security services secretly seized the web address of B92, which had been known since 1997 as the "source of independent reporting in Yugoslavia" (Larsen, 2000: 19).

Campaigns of targeted e-mail delivery, executed by the Ministry of Information, were an absolute novelty. The Minister of Information at the time, Nikola Marković, appealed to Internet users to "respect Internet ethics by sending short messages without insulting words. Messages must be sent to target groups with as many images as possible of the crimes committed. He added that the foreigners are most interested in amateur videos 
because they represent authentic footage from the field. The truth must reach influential people, politicians and business people. For that reason, messages must be sent via emails" (Larsen, 2000:18).

Since NATO managed to gradually stop television communication inside the country and with other countries, Internet sites became the primary instrument of the regime propaganda.

State services and individuals in Serbia used e-mails to inform foreign media and the global public about cases of so-called "collateral damage". For example, within 15 minutes after the Chinese Embassy was bombed, the company for geopolitical research and analytics, Stratford, received five e-mails describing attacks from people living near the embassy building (Stratford, 1999).

E-mails also became an integral part of the early warning network. The moment NATO aviation took off from Avian or other locations, Yugoslav army associates, who were stationed around the air bases, sent e-mails with information about the type of planes, their number, quantity of weapons, and their numerical designation. These pieces of information provided timely warnings to the Yugoslav Air Defense (Wall, 1999: 102).

In addition to using the Internet for public relations and for propaganda purposes, the citizens of Serbia used it to carry out information attacks against NATO countries. In the first week of bombing, more than 2000 emails infected with a virus were sent to NATO addresses in only one day (Hubbard, 1999: 11). The Alliance website was also cyberattacked by domestic hackers who managed to temporarily disable it (Putnik, 2009).

When the United States attacked Iraq on March 20, 2003 on the pretext of neutralizing weapons of mass destruction, the existing differences between the European powers became evident. Several countries of the old continent not only distanced themselves from the United States but also resolutely stood up to the armed intervention led by George Bush, holding it illegitimate for not being supported by the UN. Of course, these divisions also reflected on the way mass media reported on this war.

The presentation of the war prepared by the American media was a purified version of the conflict. The television broadcasts were mainly shot from a great height or from a distance, showing the fiery sky above Baghdad or the flat landscape of the desert along which the contours of tanks and armored vehicles were moving - more like a video game than a war.

American war reporters, the new protagonists of war journalism, protected and assisted by the army, became one of the strongest American weapons for winning the sympathy of the domestic public. Regardless of the unconditional support of most major US news networks, however, international public opinion remained rather skeptical about the necessity of military intervention (Herman, Mekčesni, 2004).

In an interview for Le Monde, Paul Virilio, a famous French philosopher, commented on the Second Gulf War by saying: "Previous conflicts were of a different nature due to the simple fact that televisions did not have the possibility to broadcast live. The real problem lies in today's speed and confusion of images." When it comes to refusing to show the horrors of war, he says: "Keeping the anonymity of victims is theatrical, it is a way of acting, a new kind of pseudo-humanitarian camouflage...we are witnessing a war of lies, a lost perception of the true and the false. The bluff is of global proportions and it is broadcast live" (Le Monde, 2003). On several occasions, Virilio has reiterated his 
criticism of the way information is spread, his thesis that the boundaries between facts and propaganda are becoming less and less defined, that technology is leading an invisible war against humanity, that there have been no differences between war and peace after World War II, and that "accidents" are the inevitable result of every technological advancement (Virilio, Lotringer, 2012).

In this conflict, the Internet had an important role as well. This time, however, it was a completely new role. During the Second Gulf War, the phenomenon of blogs came to the fore. The publishing of blogs - notes and personal diaries from war-affected areas, the description of the cruelty of the war, the interpretation of activities on the ground and the discovery of their own "truths" - had become so pervasive that Iraq had to completely abolish access to the Internet.

\section{CONCLUSION}

In modern conflicts, the winning side is the one that is faster in collecting, exploiting and manipulating information. We can say that information has become a strategic resource. Domination in the information sphere has, therefore, become the necessary precondition for success and victory in a conflict.

Becoming dominant in the information sphere is now possible because of different techniques for manipulating the content of information systems - the information which is transferred and its "package" - the tools used to shape the information and send it to the user. For this reason, certain armed conflicts, like the Gulf War, are a triumph of information, rather than arms, strategies, or the troops' morale.

And yet, it is interesting that in the second half of the twentieth and the beginning of the twenty-first century, governments did not always manage to control and adapt the informative apparatus according to their own needs owing to new media like television and the Internet. Television and the Internet changed the way news was "consumed". They transmitted events almost instantly and offered to the recipient a distinct feeling that he or she was a direct witness to war events.

More than the radio, television changed the relationship between military activities and strategies and communication resources, increasing the visibility of events. Television did not invent war, but it has become its sublimation, a necessary instrument for confirming or refuting the very causes of conflict (Remondino, 2002). Television can be said to have triumphed by imposing its model of narration and aesthetics in the conflicts that have taken place in the last decade. Before the fascinating synchronized flow of images and sounds, the viewer gets the impression that he has direct access to reality and truth. However, this is often just a misleading impression. Baudrillard, a renowned French sociologist and philosopher, speaks of television as an instrument capable of producing a reality more realistic than the real - a simulacrum, i.e. a copy of a never-existing original.

The Internet is an absolute novelty among various sources of information in contemporary conflicts. In contrast to traditional media where communication is one-way - from the sender to the recipient (the radio and television), the global computer network has enabled two-way communication. This means that, by its own nature, the medium of Internet 
allows each user to be not only the consumer, but also the creator of information. During the First Gulf War, the Internet was still underdeveloped. Only a few years later, it enabled offensive and defensive information operations in the fifth battlefield - the infosphere. In addition, the Internet has led to a revolution in the sphere of communication enabling interaction between non-state and state actors in inter-state conflicts, and the diffusion of official and unofficial, imposed and arbitrary "truths".

\section{REFERENCES}

Barbulović, S., Jevtović, Z., Lakićević, R., Popović, M. (2004). Amnezija javnosti - od propagande do terorizma. Beograd: Grafo-komerc.

Čomski, N. (2008). Kontrola medija. Novi Sad: Rubikon.

Gardner, H. (2009). "War and the media paradox". In: Athina Karatzogianni (Ed), Cyber Conflict and Global Politics. pp. 13-31. Abingdon: Routledge.

Herman, E., Mekčesni R. (2004). Globalni mediji - novi misionari korporativnog kapitalizma. Beograd: Klio.

Hubbard, Z. (1999). Information Warfare in Kosovo. Journal of Electronic Defense, Vol. 22 , No. 11 , pp. 57-60.

Larsen, A. W. (2000). Serbian Information Operations During Operation Allied Force. Alabama: Air Command and Staff College.

Le Monde, retrieved April 4, 2003, https://www.lemonde.fr/

McLuhan, M. (2008). Razumijevanje medija. Zagreb: Golden Marketing i Tehnička knjiga.

Papp, D. S., Alberts, D., Tuyahov A. (1997). "Historical Impacts of Information Technologies: An Overview". In: David S. Alberts and Daniel S. Papp (Eds.), The Information Age: An Anthology on Its Impact and Consequences, vol. I, pp. 1336. Publication Series.

Putnik, N. (2009). Sajber prostor i bezbednosni izazovi. Beograd: Univerzitet u Beogradu - Fakultet bezbednosti.

Remondino, E. (2002). La televisione va alla guerra. Roma: Sperling \& Kupfer.

Savarese, R. (1992). Guerre intelligenti. Milano: Franco Angeli.

Stratford, "Good morning America" interview with George Friedman, retrieved 15.06.1999, http://www.stratfor.com/media/ television/990615.asp

Virilio, P., Lotringer, S. (2012). Čisti rat. Beograd: Makart

Vuletć, D. (2017). Upotreba sajber prostora u kontekstu hibridnog ratovanja. Vojno delo, 7/2017, 308-325.

Wall, R. (1999). USAF Expands Infowar Arsenal. Aviation Week and Space Technology, Vol. 151, Issue 20.

Weiskopf, R., Willmott, H. (2013). "Ethics as Critical Practice: The 'Pentagon Paper', Deciding Responsibly, Truth-telling, and the Unsettling of Organizational Morality". Organization studies, Volume 34 (4), pp. 469-493 